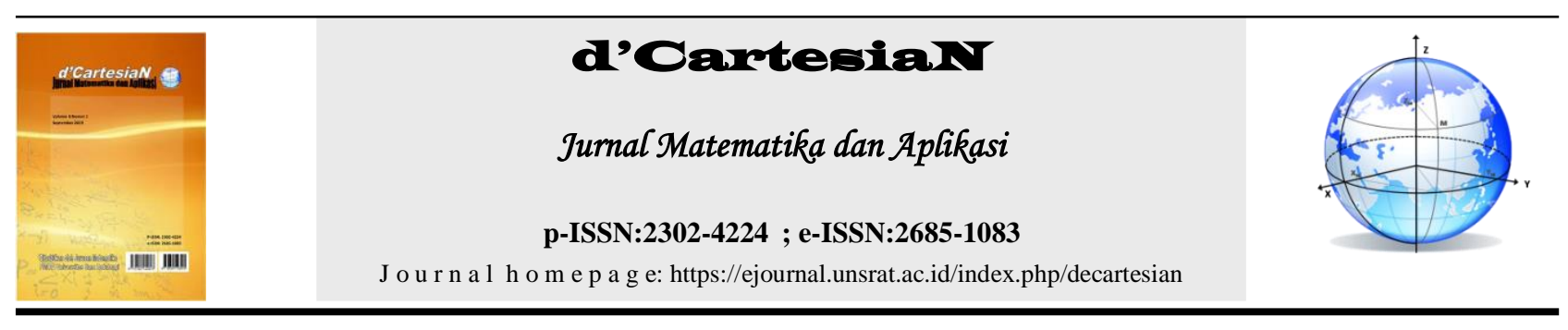

\title{
Analisis Gerombol untuk Pengelompokan Kabupaten/Kota di Sulawesi Utara Berdasarkan Produksi Hortikultura
}

\author{
Eva Damayanti ${ }^{1}$, Jantje D. Prang ${ }^{1}$, Charles E. Mongi ${ }^{*}$ \\ ${ }^{1}$ Jurusan Matematika-Fakultas Matematika dan Ilmu Pengetahuan Alam-Universitas Sam Ratulangi Manado, Indonesia \\ ${ }^{*}$ Corressponding author : charlesmongi@unsrat.ac.id
}

\begin{abstract}
A B S T RA K
Pertanian adalah suatu kegiatan manusia yang termasuk di dalamnya yaitu bercocok tanam, peternakan, perikanan dan juga kehutanan. Produksi pertanian sangatlah penting dalam kehidupan sehari-hari. Dalam penelitian ini menggunakan Analisis Gerombol yang merupakan teknik peubah ganda yang mempunyai tujuan utama untuk mengelompokan Kabupaten/Kota dan membandingkan pengelompokan analisis penggerombolan hirarki menggunakan Metode Pautan Tunggal, Pautan Lengkap, Pautan Rata-rata, Metode Centroid dan Metode Ward berdasarkan produksi pertanian di Sulawesi Utara. Dengan menggunakan Jarak Euclidian, pengerombolan pada Metode Pautan Tunggal, Pautan Lengkap, Pautan Rata-rata dan Metode Centroid terdapat 5 gerombol, sedangkan pada Metode Ward terdapat 6 gerombol. Berdasarkan gerombol akan dilihat perbandingan menggunakan rumus CTM (Cluster Tightness Measure) pada Metode Pautan Tunggal, Pautan Lengkap, Pautan Rata-rata, Metode Centroid menghasilkan nilai yang sama yaitu 0,054448 sedangkan metode Ward menghasilakan nilai 0,046549. Dapat di simpulkan bahwa pemilihan metode terbaik dalam pengerombolan adalah Metode Ward.
\end{abstract}

\section{A B S T RA C T}

Agriculture is a human activity which includes farming, livestock, fisheries and forestry. Agricultural production is very important in everyday life. In this study using cluster analysis which is a multivariate technique that has the main objective to group district/city and compare groupings of hierarchical clustering analysis using the single lingkage method, complete lingkage, average linkage, centroid method and ward method based on agricultural production in North Sulawesi. By using Euclidian Distance, the clusters on the Single Lingkage Method, Complete Lingkage, Average Lingkage and Centroid Method there are 5 clusters, while in the Ward Method there are 6 Clusters. Based on the cluster, that will see a comparison using the CTM (Cluster Tightness Measure) formula on the Single Lingkage Method, Complete Lingkage, Average Lingkage, the Centroid Method produces the same value which is 0.054448 while the Ward Method produces a value which is 0.046549 . So, it can be concluded that the selection of the best method in clustering is the Ward Method.

\section{Informasi Artikel}

Diterima : 20 Juni 2019

Diterima setelah revisi : 23 Juli 2019

Tersedia online : 25 Juli 2019

\section{Kata Kunci:}

Produksi Hortikultura, Jarak Euclidian, Pautan Tunggal, Metode Ward, CTM (Cluster Tightness Measure).

\section{Article Information \\ Received : 20 June 2019}

Received after revision : 23 July 2019

Available online : 25 July 2019

\section{Keywords:}

Horticulture Production, Euclidian Distance, Single Lingkage, Ward Method, CTM (Cluster Tightness Measure).

\section{PENDAHULUAN}

Indonesia adalah negara kepulauan yang terbentang dari Sabang sampai Marauke. Dan Indonesia merupakan negara agraris, karena mayoritas penduduk Indonesia bermata pencarian sebagai petani. Pertanian di Indonesia merupakan sektor yang menunjang terhadap kesejahteraan dan kemakmuran rakyatnya. Apabila di sektor pertanian ini berkembang dan maju, maka rakyat Indonesia akan terjamin hidupnya dengan kemakmuran [1].

Secara umum pengertian dari pertanian adalah suatu kegiatan manusia yang termasuk di dalamnya yaitu bercocok tanam, peternakan, perikanan dan juga kehutanan. Sebagian besar dari mata pencarian masyarakat di Indonesia adalah sebagai petani, sehingga sektor pertanian sangat penting untuk dikembangkan di negara kita [2].

Dalam penelitian ini menggunakan analisis gerombol yang merupakan teknik peubah ganda yang mempunyai tujuan utama untuk mengelompokkan objek-objek berdasarkan kemiripan karakteristik yang dimilikinya. Karakteristik objek-objek dalam suatu gerombol memiliki tingkat kemiripan yang tinggi, sedangkan karakteristik antar objek pada suatu gerombol dengan gerombol lain memiliki tingkat kemiripan yang rendah. Dengan kata lain, keragaman antar gerombol maksimum. Dengan menggunakan analisis gerombol peneliti bertujuan untuk dapat mengelompokkan kabupaten/kota di Sulawesi Utara berdasarkan produksi hortikultura [3].

Penelitian sebelumnya menggunakan data BPS tentang kemiskinan dengan menggunakan metode pautan tunggal, metode pautan lengkap, metode pautan rataan dan metode $k$-means. Berdasarkan kesimpulan penggerombolan kecamatan di Kabupaten Malang berdasarkan peubah status kemiskinan dengan metode pautan tunggal menghasilkan 4 gerombol. Penggerombolan dengan metode pautan lengkap, metode pautan rataan dan metode $k$-means $(\mathrm{k}=2)$ 
menghasilkan 2 gerombol yang sama. Hasil penggerombolan kecamatan di Kabupaten Malang berdasarkan peubah status kemiskinan yang dianggap paling mewakili adalah 2 gerombol. Hal ini ditunjang oleh 3 metode yaitu metode pautan lengkap, metode pautan rataan, dan metode $k$-means $(\mathrm{k}=2)$. Ketiga metode tersebut menghasilkan gerombol sama dengan 2. Gerombol I tidak memiliki ciri yang menonjol karena tidak ada peubah yang memiliki rata-rata lebih tinggi dibandingkan gerombol II semua peubahnya cenderung berada di sekitar rata-rata total [4].

Dalam Analisis Gerombol dengan Metode Hirarki yaitu Analisis yang penggerombolan datanya dilakukan dengan cara mengukur jarak kedekatan pada setiap objek yang kemudian membentuk sebuah dendogram. Pada penelitian ini menggunakan ke-5 Metode Analisis penggerombolan berhirarki (Metode Pautan tunggal, Pautan Lengkap, Pautan Rata-rata, Metode Centroid, dan Metode Ward) dengan menggunakan jarak Euclidian. Untuk dapat mengelompokan Kabupaten/Kota dan membandingkan ke-5 Metode Hirarki berdasarkan kemiripan karakteristik dari sudut pandang pertanian dengan Analisis Gerombol.

\section{Analisis Gerombol}

Analisis Gerombol merupakan suatu metode peubah ganda yang bertujuan untuk mengelompokkan $n$ objek pengamatan ke dalam $m$ gerombol $(m<n)$ berdasarkan $p$ peubah, sehingga setiap pengamatan yang terletak dalam satu gerombol mempunyai kemiripan sifat yang lebih besar dibandingkan dengan pengamatan yang terletak pada gerombol lain [5].

Analisis gerombol berhubungan dengan data berbentuk tabel dimana baris menyatakan objek, organisme atau individu dan kolom menyatakan peubah atau karakteristik. Dasar penggerombolan $n$ objek ke dalam $m$ Gerombol adalah jarak, yang merupakan ukuran kedekatan antara masing-masing objek. Dalam menentukan jarak harus diperhatikan satuan peubahpeubahnya, jika satuan peubah tidak sama maka perlu dilakukan pembakuan atau standarisasi peubah [6].

Adapun jarak yang biasa digunakan dalam analisis penggerombolan diantaranya adalah jarak Euclidian, jarak mahalanobis, jarak manhattan, jarak log likehood [7].

\subsection{Pemilihan jarak \\ 2.1.1. Jarak Euclidian}

Jarak Euclidian adalah jarak yang paling umum dan paling sering digunakan dalam analisis gerombol. Jarak Euclidian antara dua titik dapat terdefinisikan dengan jelas. Jarak yang digunakan kontinu. Jarak Euclidian antara gerombol ke- $i$ dan ke- $j$ dari $p$ peubah dirumuskan sebagai berikut [8]:

$$
d(i, k)=\sqrt{\sum_{j=1}^{p}\left(x_{i j}-x_{k j}\right)^{2}}
$$

Dengan:

$d(i, k)=$ Jarak antara objek $i$ ke objek $k$

$x_{i j}=$ Nilai data ke- $i$ pada variabel ke- $j$

$x_{k j} \quad=$ Nilai data ke- $k$ pada variabel ke- $j$

$p \quad=$ Banyaknya peubah yang diamati.

\subsubsection{Jarak Mahalanobis}

Jarak Mahalanobis sangat berguna dalam menghilangkan atau mengurangi perbedaan skala pada masing-masing komponen. Pada permasalahan tertentu, pada saat menentukan jarak, perlu juga dipertimbangkan ragam dan peragaman. Jarak Mahalanobis dirumuskan sebagai berikut [9]:

$$
d(i, j)=\left[\left(\bar{x}_{i}-\bar{x}_{j}\right) S^{-1}\left(\bar{x}_{i}-\bar{x}_{j}\right)\right]^{1 / 2}
$$

Dengan:

$$
\begin{aligned}
& d(i, j)=\text { Jarak antara objek } i \text { ke objek } j \\
& \bar{x}_{j}=\text { Nilai tengah pada gerombol ke- } j \\
& \bar{x}_{i}=\text { Nilai tengah pada gerombol ke- } i \\
& S^{-1}=\text { Matriks ragam peragam gabungan antara. }
\end{aligned}
$$

\subsubsection{Jarak Manhattan}

Jarak Manhattan antara dua objek merupakan jumlah nilai perbedaan mutlak untuk tiap variabel. Jarak ini juga disebut jarak Minkowski. Ukuran ini merupakan bentuk umum dari jarak Euclidian, fungsi jaraknya dirumuskan sebagai berikut [9]:

Jika $\underline{x}^{\prime}=\left(x_{1}, x_{2}, \ldots, x_{p}\right) ; p$ adalah variabel, maka

$x^{\prime}=\left(x_{i 1}, x_{i 2}, \ldots, x_{i p}\right)$ adalah kumpulan variabel pada objek ke- $i$

Dengan:

$$
d(i, j)=\left[\sum_{k=1}^{p}\left|x_{i k}-y_{i k}\right|^{r}\right]^{1 / r}
$$

$d(i, j)=$ Jarak antara objek $i$ ke objek $j$

$\bar{x}_{j} \quad=$ Nilai tengah pada Gerombol ke- $j$

$\bar{x}_{i} \quad=$ Nilai tengah pada Gerombol ke- $i$

$p \quad=$ Banyaknya peubah yang diamati

$d_{y} \quad=$ jarak antara dua objek ke- $i$ dan objek ke- $j$

\subsubsection{Jarak Log Likehood}

Jarak Log Likehood dapat ditetapkan untuk peubah kontinu maupun kategorik. Jarak antara gerombol $j$ dengan gerombol $s$ dirumuskan pada persamaan 4 [9]:

$$
d(j, s)=\xi_{j}+\xi_{s}-\xi_{(j, s)}
$$

\subsection{Metode Penggerombolan Berhirarki}

Metode penggerombolan berhirarki digunakan apabila banyak gerombol yang akan dibentuk belum diketahui sebelumnya. Pada metode berhirarki terdapat 2 cara pembentukan gerombol yaitu agglomerative dan divisive. Metode hirarki agglomerative dimulai dengan masing-masing objek adalah satu gerombol kemudian digabungkan berdasarkan kesamaan objek sampai menjadi hanya satu gerombol saja yang berisi semua objek. Sedangkan metode hirarki divisive adalah kebalikannya dimulai dengan satu gerombol yang anggotanya adalah seluruh objek, kemudian objek-objek yang paling jau dipisah dan membentuk gerombol lain. Proses ini berlanjut sampai semua objek masing-masing membentuk satu gerombol [10].

Metode-metode yang bisa digunakan dalam metode hirarki adalah metode Agglomeratif (Agglomerative Method) dan metode Defisif (Devisive Method) [11].

\subsubsection{Metode Agglomeratif (Agglomerative Method)}

Metode Agglomeratif dimulai dengan menganggap bahwa setiap objek adalah sebuah gerombol. Kemudian dua objek dengan jarak terdekat digabungakan menjadi satu gerombol. Selanjutnya objek ketiga akan bergabung dengan gerombol yang ada atau bersama objek lain dan membentuk gerombol baru dengan tetap memperhitungkan jarak kedekatan antar objek. Proses akan berlanjut hingga akhirnya terbentuk satu gerombol yang terdiri dari keseluruhan objek.

Metode Hirarki Agglomeratif (Agglomerative Method) masih ada lima metode dalam pembentukan gerombol yaitu [12]:

1. Pautan Tunggal (Single Linkage)

2. Pautan Lengkap (Complete Linkage) 
3. Pautan Rata-rata (Average Linkage)

4. Metode Centroid (Pusat)

5. Metode Ward (Ward's Method).

Berikut penjelasan mengenai beberapa pautan dalam metode penggerombolan hirarki [5]:

\subsubsection{Pautan Tunggal}

Jarak dua gerombol diukur dengan jarak terdekat antara sebuah objek dalam gerombol yang satu dengan sebuah objek dalam gerombol lain [5].

$$
d_{m j}=\min \left(d_{k j}, d_{l j}\right)
$$

Dengan:

$d_{m j}=$ jarak antara gerombol $m$ dan gerombol $j$.

$d_{k j}=$ jarak antara tetangga terdekat gerombol $k$ dan $j$,

$d_{l j}=$ jarak antara tetangga terdekat gerombol $l$ dan $j$.

\subsubsection{Pautan Lengkap}

Jarak dua gerombol diukur dengan jarak terjauh antara sebuah objek dalam gerombol yang satu dengan sebuah objek dalam gerombol yang lain [5].

$$
d_{m j}=\max \left(d_{k j}, d_{l j}\right)
$$

\subsubsection{Pautan Rata-rata}

Jarak antara dua gerombol diukur dengan jarak rata-rata antara sebuah objek dalam gerombol yang satu dengan sebuah objek dalam gerombol yang lain [5].

$$
d_{m j}=\frac{N_{k} d_{k j}+N_{l} d_{l j}}{N_{m}}
$$

Dengan:

$$
N_{k}, N_{l} \text { dan } N_{m}=\underset{k, l, m}{\text { jumlah objek dalam gerombol ke- }}
$$

\subsubsection{Metode Centroid}

Jarak antara dua buah gerombol diukur sebagai jarak Euclidian antara kedua rataan (centroid) gerombol. Metode Centroid adalah nilai tengah obsevasi pada variabel dalam suatu set variabel cluster. Keuntungannya adalah outlier hanya sedikit berpengaruh jika dibandingkan dengan metode lain, yang dihitung dengan formulasi [13].

$$
d_{m j}=\frac{N_{k} d_{k j}+N_{l} d_{l j}}{N_{m}}-\frac{N_{k} N_{l} d_{k l}}{N_{m}{ }^{2}}
$$

Dengan:

$$
N_{k}, N_{l}, N_{m}=\underset{k, l, m}{\text { jumlah }} \text { objek dalam gerombol ke- }
$$

\subsubsection{Metode Ward}

Jarak antara dua gerombol adalah jumlah kuadrat penyimpangan dari metode centroid. Tujuan dari metode ward adalah untuk meminimalkan dalam cluster sum of squares.

$$
d_{m j}=\frac{\left(N_{j}+N_{k}\right) d_{k j}+\left(N_{j+} N_{l}\right) d_{l j}-N_{j} d_{k l}}{N_{j}+N_{m}}
$$

Metode ini berbeda dengan metode lainnya karena menggunakan pendekatan analisis varians untuk menghitung jarak antar gerombol atau metode ini meminimumkan jumlah kuadrat (SSE). SSE hanya dapat dihitung jika Gerombol memiliki elemen lebih dari satu objek. SSE Gerombol yang hanya memiliki satu objek adalah nol. Metode Ward ini dihitung berdasarkan persamaan berikut [14]:

Dengan:

$$
S S E=\sum_{i=1}^{N}\left(X_{i}-\bar{X}\right)^{\prime}\left(X_{i}-\bar{X}\right)
$$

$$
\text { SSE = Sum of Square Error }
$$

$X_{i} \quad=$ Vektor kolom yang entrinya nilai objek ke- $i$ dengan $i=1,2,3, \ldots, N$

$\bar{X} \quad=$ Vektor kolom yang entrinya rata-rata nilai objek dalam Gerombol

$$
\mathrm{N} \text { = Banyaknya objek. }
$$

\subsubsection{Metode Defisif (Devisive Method)}

Proses pengelompokan dengan pendekatan metode pemecahan (Top to Down) dimulai dengan $n$ objek yang dikelompokan menjadi satu gerombol, kemudian gerombol tersebut dipartisi ke dalam dua gerombol pada setiap langkah diperoleh $n$ gerombol dengan setiap gerombol memiliki satu objek. Dasar pengelompokan juga didasarkan pada jarak. Akan tetapi, teknik ini tidak banyak digunakan, sehingga tidak banyak prodesur yang dikembangkan [15].

\subsection{Pemilihan Metode Terbaik}

Pemilihan metode terbaik dalam penggerombolan dapat dilihat dari keragaman yang terbentuk, semakin kecil nilai keragamannya, maka hasil penggelompokkan semakin baik. Cluster Tightness Measure (CTM) merupakan ukuran kebaikan dari hasil pengelompokan berdasarkan simpangan baku setiap variabel pada masing-masing kelompok. Jika CTM bernilai nol, artinya semua data berada pada pusat kelompok. Metode pengelompokan terbaik dengan menggunakan nilai CTM dihitung dengan persamaan [16]:

$$
\begin{aligned}
& S_{t m}=\begin{array}{c}
\text { Simpangan baku pada kelompok ke- } t \text { untuk } \\
\text { variabel ke- } m
\end{array} \\
& S_{m}=\begin{array}{l}
\text { Simpangan baku seluruh data untuk variabel } \\
\text { ke- } m
\end{array} \\
& K=\text { Banyaknya kelompok } \\
& P \quad=\text { Banyaknya variabel. }
\end{aligned}
$$
Dengan:$$
C T M=\frac{1}{K} \sum_{t=1}^{K}\left(\frac{1}{P} \sum_{m=1}^{P} \frac{S_{t m}}{S_{m}}\right)
$$

\section{METODE PENELITIAN}

\subsection{Waktu dan Tempat Penelitian}

Penelitian ini dilaksanakan dari bulan Desember 2018 sampai Febuari 2019, mulai dari penyusunan proposal, pengambilan data serta pengolahan data. Pengambilan data dilakukan di Badan Pusat Statistik (BPS) Provinsi Sulawesi Utara dan pengolahan data dilakukan di Laboratorium Statistika, Fakultas Matematika dan Ilmu Pengetahuan Alam, Universitas Sam Ratulangi Manado.

\subsection{Jenis dan Sumber Data}

Jenis data yang digunakan dalam penelitian ini adalah data sekunder, dari Badan Pusat Statistik (BPS) Sulawesi Utara data produksi hortikultura 2017 [17].

\subsection{Variabel dan Objek Penelitian}

Variabel dari penelitian ini adalah produksi hortikultura Sulawesi Utara. Pada produksi hortikultura terdapat 26 variabel tapi disini peneliti hanya menggunakan 11 variabel karena pada variabel lainnya terdapat banyak o sehingga hanya diambil 11 variabel. 11 variabel tersebut disajikan pada Tabel 1:

Objek dari penelitian ini adalah Kabupaten/Kota di Sulawesi Utara dan objek-objek yang digunakan disajikan pada Tabel 2: 
Tabel 1. Variabel Penelitian

\begin{tabular}{cl}
\hline \multicolumn{2}{c}{ Produksi Hortikultura } \\
\hline Variabel & \multicolumn{1}{c}{ Keterangan } \\
\hline X1 & Tomat \\
X2 & Cabai Rawit \\
X3 & Kangkung \\
X4 & Cabai Besar \\
X5 & Kacang Panjang \\
X6 & Terung \\
X7 & Ketimun \\
X8 & Labu Siam \\
X9 & Bayam \\
X10 & Kacang Merah \\
X11 & Bawang Daun \\
\hline
\end{tabular}

Tabel 2. Objek Penelitian

\begin{tabular}{cl}
\hline & Kabupaten/Kota \\
\hline Objek & \multicolumn{1}{c}{ Keterangan } \\
\hline Y1 & Bolaang Mongondow \\
Y2 & Minahasa \\
Y3 & Kepulauan Sangihe \\
Y4 & Kepulauan Talaud \\
Y5 & Minahasa Selatan \\
Y6 & Minahasa Utara \\
Y7 & Bolaang Mongondow Utara \\
Y8 & Kepulauan Sitaro \\
Y9 & Minahasa Tenggara \\
Y10 & Bolaang Mongondow Selatan \\
Y11 & Bolaang Mongondow Timur \\
Y12 & Kota Manado \\
Y13 & Kota Bitung \\
Y14 & Kota Tomohon \\
Y15 & Kota Kotamobagu \\
\hline
\end{tabular}

\subsection{Metode Analisis}

Adapun langkah-langkah Analisis data untuk penelitian tentang produksi hortikultura di Kabupaten/Kota Provinsi Sulawesi Utara pada tahun 2017 antara lain:

1. Melakukan Analisis statistika deskriptif untuk mengkaji karakteristik kabupaten/kota di provinsi Sulawesi utara yang di sajikan berupa tabel dengan menggunakan Aplikasi Minitab 17.

2. Melakukan hasil Analisis Penggerombolan pada metode Pautan Tunggal, Pautan Lengkap, Pautan Rata-rata, Metode Centroid, dan Metode Ward yang di sajikan dalam bentuk dendogram, setelah itu dilakukan cara pemotongan dendogram dan penggelompokan produksi hortikultura.

3. Menentukan metode terbaik diantara metode Pautan Tunggal, Pautan Lengkap, Pautan Rata-rata, Metode Centroid, dan Metode Ward pada analisis gerombol hirarki dengan menggunakan rumus CTM.

4. Menginterprestasikan hasil Analisis Gerombol Kabupaten/Kota pada Produksi hortikultura.

\subsection{Diagram Alir (Flowchart) Penelitian}

Selanjutnya, dibuat diagram alir digunakan untuk membantu analisis data yang disajikan pada Gambar 1 .

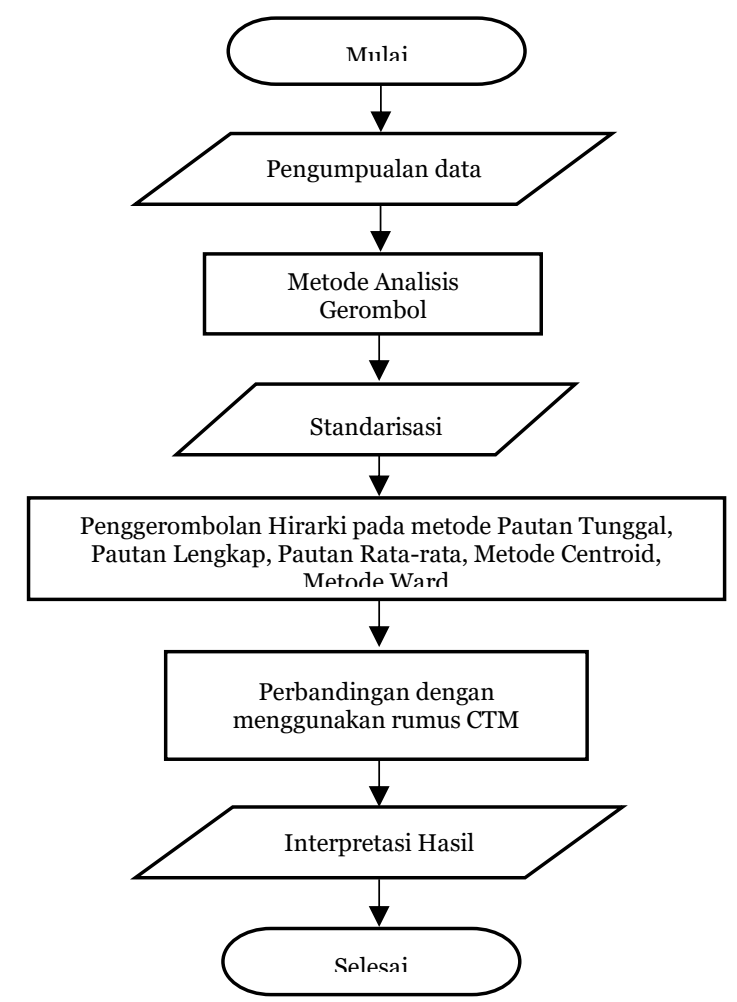

Gambar 1. Diagram Alir Penelitian.

\section{HASIL DAN PEMBAHASAN}

4.1. Statistik Deskriptif Karateristik Produksi Hortikultura di Sulawesi Utara

Sebelum dilaksanakan analisis gerombol terlebih dahulu di analisis secara deskriptif. Dalam menentukan deskriptif statistik di sajikan dengan menggunakan tabel. Dari 15 Kabupaten/Kota di Sulawesi Utara, di hasilkan distribusi produksi hortikultura seperti pada Tabel 3 data produksi hortikultura hasil statistik deskriptif tiap variabel seluruh Sulawesi utara 2017 dalam satuan kuintal.

Berdasarkan Tabel 3, terdapat 11 variabel dan 15 Kabupaten/Kota, dimana 11 variabel tersebut terdapat produksi Tomat, Cabai Rawit, Kangkung, Cabai Besar, Kacang Panjang, Terung, Ketimun, Labu Siam, Bayam, Kacang Merah dan Bawang Daun. Sedangkan 15 Kabupaten/Kota terdapat Kabupaten Bolaang Mongondow, Kabupaten Minahasa, Kabupaten Kepulauan Sangihe, Kabupaten Kepulauan Talaud, Kabupaten Minahasa Selatan, kabupaten Minahasa Utara, Kabupaten Bolaang Mongondow Utara, Kabupaten Kepulauan Sitaro, Kabupaten Minahasa Tenggara, Kabupaten Bolaang Mongondow Selatan, Kabupaten Bolaang Mongondow Timur, Kabupaten Kota Manado, Kabupaten Kota Bitung, Kabupaten Kota Tomohon, dan Kabupaten Kota Kotamobagu. 
Tabel 3. Hasil Statistik Deskriptif tiap Variabel (Produksi Hortikultura) seluruh Sulawesi Utara 2017 dalam satuan kuintal.

\begin{tabular}{lcccc}
\hline Variabel & $\begin{array}{c}\text { Rata- } \\
\text { rata }\end{array}$ & $\begin{array}{c}\text { Simpangan } \\
\text { Baku }\end{array}$ & Minimum & Maksimum \\
\hline Tomat & 20.184 & 36.951 & 13 & 135.337 \\
Cabai & 8.870 & 15.352 & 279 & 55.783 \\
Rawit & 2.665 & 3.956 & 0 & 15.291 \\
Kangkung & 3.251 & 6.036 & 0 & 22.038 \\
Cabai & 1.763 & 2.357 & 10 & 8.772 \\
$\begin{array}{l}\text { Besar } \\
\text { Kacang }\end{array}$ & 4.132 & 6.883 & 9 & 20.49 \\
$\begin{array}{l}\text { Panjang } \\
\text { Terung }\end{array}$ & 2.555 & 3.519 & 0 & 10.869 \\
$\begin{array}{l}\text { Ketimun } \\
\text { Labu }\end{array}$ & 4.273 & 10.549 & 0 & 38.455 \\
Siam & 670 & 867 & 0 & 3.101 \\
$\begin{array}{l}\text { Bayam } \\
\text { Kacang }\end{array}$ & 552 & 1.318 & 0 & 5.164 \\
$\begin{array}{l}\text { Merah } \\
\text { Bawang }\end{array}$ & 24.924 & 59.829 & 0 & 230.200 \\
Daun & & & & \\
\hline
\end{tabular}

Cara pengambilan rata-rata dilakukan dengan cara dijumlahkan semua produksi tomat pada 15 kabupaten/kota kemudian dibahagi 15, dilakukan hal yang sama pada produksi cabai rawit, produksi kangkung, produksi cabai besar, produksi kacang panjang, produksi terung, produksi ketimun, produksi labu siam, produksi bayam, produksi kacang merah, dan produksi bawang daun. Sehingga Produksi Bawang Daun secara rata-rata merupakan produksi tertinggi di Sulawesi Utara, kemudian diikuti dengan Produksi Tomat secara rata-rata merupakan produksi tertinggi kedua sedangkan Produksi Cabai Rawit merupakan produksi tertinggi ketiga. Untuk produksi terendah secara rata-rata ialah Produksi Kacang Merah. Simpangan Baku atau Standar deviasi bisa juga didefinisikan sebagai, rata-rata jarak penyimpangan titik-titik data diukur dari nilai rata-rata data. Simpangan baku tertinggi terdapat pada Produksi Bawang Daun, tertinggi kedua pada Produksi Tomat dan standar deviasi terendah pada produksi Bayam. Simpangan $B a k u=\sqrt{V a r}$, dimana varians atau ragam suatu peubah acak (Distribusi Probabilitas) adalah ukuran seberapa jauh sebuah kumpulan bilangan tersebar. Minimum atau nilai terkecil, terdapat beberapa nilai nol yaitu pada Produksi Kangkung, Produksi Cabai Besar, Produksi Ketimun, Produksi Labu Siam, Produksi Bayam, Produksi Kacang Merah dan Produksi Bawang Daun. Sedangkan Maximum atau nilai terbesar, terdapat pada Produksi Bawang Daun, Produksi Tomat dan Produksi Cabai Rawit.

\subsection{Hasil Analisis Gerombol}

Pada hasil penelitian Analisis Gerombol ini dilakukan dengan menggunakan jarak Euclidean dan Metode Pautan Tunggal, Pautan Lengkap, Pautan Ratarata, Metode Centroid, dan Metode Ward. Pengelompokan produksi hortikultura dilakukan dengan menggunakan aplikasi Minitab 17.

\subsubsection{Metode Ward}

Hasil pengerombolan Metode Ward berdasarkan distance level 2,4545 step ke-9 terdapat 6 gerombol yang disajikan pada Gambar 2.

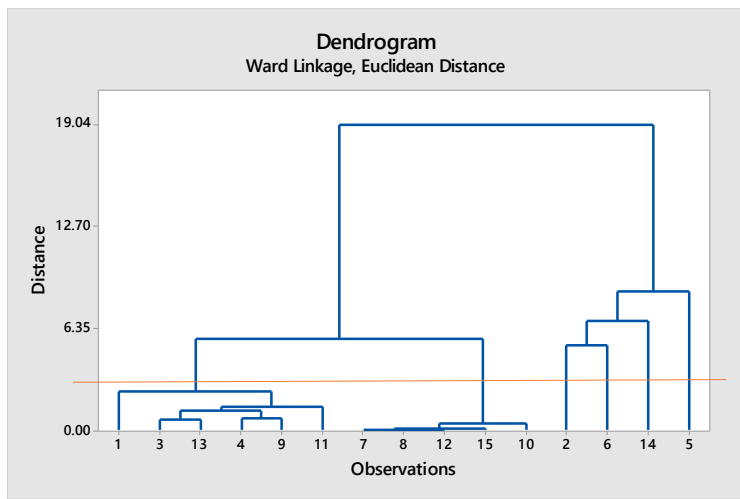

Gambar 2. Dendogram Hasil Analisis Gerombol dengan menggunakan Metode Ward.

Pemotongan dendogram pada metode pautan tunggal, pautan lengkap, pautan rata-rata dan metode centroid sama seperti metode ward dengan melihat distance level terjauh. Berdasarkan jarak terjauh metode pautan tunggal terdapat pada step ke-10 dengan distance level 1,60697 menghasilkan 5 gerombol, pautan lengkap dengan distance level 2,79180, pautan rata-rata dengan distance level 2,33341 dan metode ward dengan distance level 1,85525 menghasilkan 5 gerombol.

\subsection{Perbandingan Antara Pengelompokan Analisis Gerombol Hirarki}

Untuk mengetahui metode terbaik dalam analisis penggerombolan hirarki, digunakan CTM (Cluster Tightness Measure), dimana semakin kecil nilai keragamannya, maka hasil pengelompokkan semakin baik. Jika CTM bernilai nol, artinya semua data berada pada pusat kelompok.

Dari proses penggerombolan menggunakan ke- 5 metode hirarki yang telah dijelaskan sebelumnya. Langkah selanjutnya dihitung nilai CTM, Sebelum menghitung nilai CTM terlebih dahulu mencari nilai simpangan baku pada kelompok ke- $t$ untuk variabel ke$m\left(s_{t m}\right)$ dan mencari nilai simpangan baku variabel ke$m\left(s_{m}\right)$.

\subsection{Pemilihan Metode Terbaik Menggunakan Rumus CTM (Cluster Tightness Measure)}

Sebelum menentukan pemilihan metode terbaik, terlebih dahulu dilakukan pembentukan Gerombol seperti yang sudah di jelaskan pembentukan gerombol dilakukan dengan pemotongan dendogram yang dilihat berdasarkan distance level terjauh antar simpul yang satu dengan simpul yang lain. Hasil Pengerombolan disajikan pada Tabel 4 .

Tabel 4. Pengelompokan Produksi Hortikultura

\begin{tabular}{lcccccc}
\hline \multirow{2}{*}{ METODE } & \multicolumn{7}{c}{ GEROMBOL } & & & \\
\cline { 2 - 7 } & II & III & IV & V & VI \\
\hline Pautan & $1,3,13,4,9,11$, & 6 & 2 & 5 & 14 & \\
Tunggal & $7,8,12,15,10$ & & & & & \\
$\begin{array}{l}\text { Pautan } \\
\text { lengkap }\end{array}$ & $1,3,13,4,9,11$, & 6 & 5 & 2 & 14 & \\
$\begin{array}{l}\text { Pautan } \\
\text { rata-rata }\end{array}$ & $\begin{array}{c}1,8,12,15,10 \\
7,8,13,4,9,11,\end{array}$ & 6 & 5 & 2 & 14 & \\
$\begin{array}{l}\text { Metode } \\
\text { Centroid }\end{array}$ & $1,3,13,4,9,11$, & 6 & 5 & 2 & 14 & \\
Metode & $7,8,12,15,10$ & & & & & \\
Ward & $1,3,13,4,9,11$ & $7,8,12$, & 2 & 6 & 14 & 5 \\
\hline
\end{tabular}




\subsubsection{Metode Ward}

Berdasarkan jarak terjauh Metode Ward menghasilkan 6 Gerombol, Gerombol pertama terdapat 6 kelompok dan Gerombol kedua terdapat 5 kelompok sedangkan Gerombol 3, Gerombol 4, Gerombol 5 dan Gerombol 6 hanya menghasilkan 1 kelompok. Perhitungan Pemilihan Metode terbaik untuk Metode Ward sama dengan Metode Pautan Tunggal.

$>$ Simpangan baku pada kelompok ke-t untuk variabel ke- $m\left(s_{t m}\right)$

- $\quad$ Gerombol 1

$$
\begin{aligned}
& S_{1}=\sqrt{\frac{\left(X_{1}-\bar{X}\right)^{2}+\cdots+\left(X_{n}-\bar{X}\right)^{2}}{n-1}} \\
& S_{1}=\sqrt{\frac{(17.939-9.278,833)^{2}+\cdots+(558-9.278,833)^{2}}{6-1}} \\
& S_{1}=\sqrt{\frac{435.751 .678,8}{5}} \\
& S_{1}=9.335,434418
\end{aligned}
$$

Untuk hasil keseluruhan nilai $S_{1}, \ldots, S_{11}$. Terdapat pada Tabel 5 .

Tabel 5. Simpangan Baku seluruh variabel pada Gerombol 1 dengan menggunakan Metode Ward.

\begin{tabular}{cc}
\hline Simpangan Baku & Nilai \\
\hline S1 & $9.335,434418$ \\
S2 & $2.855,469308$ \\
S3 & 658,292868 \\
S4 & $1.832,009762$ \\
S5 & 342,8308135 \\
S6 & $1.100,285493$ \\
S7 & 735,8868572 \\
S8 & 598,9836114 \\
S9 & 512,5346492 \\
S10 & 414,1982215 \\
S11 & $27.626,5122$
\end{tabular}

- $\quad$ Gerombol 2

$$
\begin{aligned}
& S_{1}=\sqrt{\frac{\left(X_{1}-\bar{X}\right)^{2}+\cdots+\left(X_{n}-\bar{X}\right)^{2}}{n-1}} \\
& S_{1}=\sqrt{\frac{(67-62,8)^{2}+\cdots+(36-62,8)^{2}}{5-1}} \\
& S_{1}=\sqrt{\frac{13.278,8}{4}} \\
& S_{1}=57,617
\end{aligned}
$$

Untuk hasil keseluruhan nilai $S_{1}, \ldots, S_{11}$, terdapat pada Tabel 6.

Perhitungan simpangan baku seluruh variabel $\left(s_{t m}\right)$ metode ward gerombol 1 dapat dilihat pada tabel 7 dan gerombol 2 pada tabel 8, sedangkan gerombol 3, gerombol 4, gerombol 5 dan gerombol 6 pada metode ward hanya terdapat 1 kelompok yang mengakibatkan nilai simpangan baku seluruh variabel $\left(s_{t m}\right)$ menghasilkan o.

Tabel 6. Simpangan Baku seluruh variabel pada Gerombol 2 dengan menggunakan Metode Ward.

\begin{tabular}{cc}
\hline Simpangan Baku & Nilai \\
\hline S1 & 57,61683782 \\
S2 & $2.120,046462$ \\
S3 & 189,8768022 \\
S4 & 39,7893253 \\
S5 & 20,90932806 \\
S6 & 34,7807418 \\
S7 & 735,8868572 \\
S8 & 7,155417528 \\
S9 & 10,91787525 \\
S10 & 0 \\
S11 & 5,196152423 \\
\hline
\end{tabular}

$>$ Perhitungan $\frac{1}{P} \sum_{m=1}^{P} \frac{S_{t m}}{S_{m}}$ pada Gerombol I, Gerombol II, Gerombol III, Gerombol IV, Gerombol V dan Gerombol VI.

- Gerombol 1

$$
\begin{aligned}
\frac{1}{P} \sum_{m=1}^{P} \frac{S_{t m}}{S_{m}} & =\frac{1}{11}\left(\left(\frac{9.335,434}{36.950,860}+\cdots+\frac{27.626,5122}{59.829,465}\right)\right) \\
& =\frac{1}{11}((0,253+\cdots+0,462)) \\
& =\frac{1}{11}((2.847)) \\
& =0,259
\end{aligned}
$$

- Gerombol 2

$$
\begin{aligned}
\frac{1}{P} \sum_{m=1}^{P} \frac{S_{t m}}{S_{m}} & =\frac{1}{11}\left(\left(\frac{57,617}{36.950,860}+\cdots+\frac{5,196}{59.829,465}\right)\right) \\
& =\frac{1}{11}((0,002+\cdots+8,685)) \\
& =\frac{1}{11}((0,226)) \\
& =0,021
\end{aligned}
$$

Pada Gerombol 3, Gerombol 4, Gerombol 5 dan Gerombol 6 dengan memasukan nilai kedalam rumus $\frac{1}{P} \sum_{m=1}^{P} \frac{S_{t m}}{S_{m}}$ menghasilkan nilai o karena nilai $S_{t m}$ pada Gerombol 2, Gerombol 3, Gerombol 4, Gerombol 5 dan gerombol 6 menghasilkan 0 yang jika dibagikan angka berapapun hasilnya pasti 0 .

$>\quad$ Perhitungan nilai CTM

$$
\begin{aligned}
& C T M=\frac{1}{K} \sum_{t=1}^{K}\left(\frac{1}{P} \sum_{m=1}^{P} \frac{S_{t m}}{S_{m}}\right) \\
& C T M=\frac{1}{6}(0,252645+0,001559+0+0+0+0) \\
& C T M=0,046549
\end{aligned}
$$

Jadi perhitungan nilai CTM dengan menggunakan metode pautan tunggal adalah 0,054448 dan metode ward adalah 0,046549 sedangkan metode pautan lengkap, pautan rata-rata dan metode centroid menghasilkan nilai yang sama dengan metode pautan tunggal karena terdapat pengelompokan yang juga sama. Hasil perbandingan disajikan pada Tabel 7. 
Tabel 7. Nilai CTM dengan menggunakan Metode Pautan Tunggal, Pautan Lengkap, Pautan Rata-rata, Metode Centroid dan Metode Ward.

\begin{tabular}{lc}
\hline \multicolumn{1}{c}{ Metode } & Nilai CTM \\
\hline Pautan Tunggal & 0,054448 \\
Pautan Lengkap & 0,054448 \\
Pautan Rata-rata & 0,054448 \\
Metode Centroid & 0,054448 \\
Metode Ward & 0,046549 \\
\hline
\end{tabular}

Berdasarkan tabel 9, nilai CTM menunjukkan bahwa tidak besar pengaruh nilai CTM antar metode, sehingga dapat dikatakan metode pautan tunggal, pautan lengkap, pautan rata-rata, metode centroid dan metode ward memiliki kinerja yang sama baiknya.

\subsection{Interpretasi Hasil Analisis Gerombol Kabupaten/Kota pada Produksi Hortikultura}

Setelah melakukan perbandingan pengelompokan analisis gerombol hirarki, maka selanjutnya MengInterpretasikan dengan menggunakan metode ward pada produksi hortikultura. Pada metode ward terdapat 6 gerombol bisa dilihat pada tabel 8 .

Tabel 8. Penggerombolan Produksi hortikultura dengan menggunakan Metode Ward.

\begin{tabular}{cl}
\hline & \multicolumn{1}{c}{ Metode Ward } \\
\hline Gerombol 1 & $\begin{array}{l}\text { Kabupaten Bolaang Mongondow, } \\
\text { Kabupaten Kepulauan Sangihe, Kota } \\
\text { Bitung, Kabupaten Talaud, Kabupaten } \\
\text { Minahasa Tenggara, Kabupaten } \\
\text { Bolaang Mongondow Timur }\end{array}$ \\
Gerombol 2 & $\begin{array}{l}\text { Kabupaten Bolaang Mongondow } \\
\text { Ktara, Kabupaten Kepulauan Sitaro, } \\
\text { Kabupaten Bolaang Mongondow } \\
\text { Selatan }\end{array}$ \\
Gerombol 3 & $\begin{array}{l}\text { Kabupaten Minahasa } \\
\text { Gerombol 4 } 4\end{array}$ \\
Kerombol 5 & Kota Tomohon \\
Gerombol 6 & Kabupaten Minahasa Selatan \\
\hline
\end{tabular}

Pada Tabel 10 diatas dapat dilihat bahwa, gerombol pertama terdapat 6 kabupaten/kota yaitu, Kabupaten Bolaang Mongondow, Kabupaten Kepulauan Sangihe, Kota Bitung, Kabupaten Kepulauan Talaud, Kabupaten Minahasa Tenggara, Kabupaten Bolaang Mongondow Timur. Gerombol kedua terdapat 5 kabupaten/kota yaitu, Kabupaten Bolaang Mongondow Utara, Kabupaten kepulauan Sitaro, Kota Manado, Kota Kotamobagu dan Kabupaten Bolaang Mongondow Selatan, gerombol ketiga terdapat 1 kabupaten/kota yaitu, Kabupaten Minahasa, gerombol keempat terdapat
1 kabupaten/kota yaitu Kabupaten Minahasa Utara, gerombol kelima terdapat 1 kabupaten/kota yaitu Kota Tomohon dan gerombol keenam juga terdapat 1 kabupaten/kota yaitu Kabupaten Minahasa Selatan.

Gerombol pertama secara rata-rata produksi tertinggi adalah produksi bawang baun dengan $17.749,5 \mathrm{~kg}$ dan produksi terendah secara rata-rata adalah produksi kacang merah dengan 293,167 $\mathrm{kg}$. Gerombol kedua secara rata-rata produksi tertinggi adalah produksi cabai rawit dengan $1.298 \mathrm{~kg}$, produksi terendah secara rata-rata adalah produksi bawang daun dengan $3 \mathrm{~kg}$ dan ada juga yang tidak memproduksi pada gerombol kedua yaitu produksi kacang merah. Gerombol ketiga produksi terbanyak ialah produksi tomat dengan $69.470 \mathrm{~kg}$ dan produksi cabai rawit dengan $30.589 \mathrm{~kg}$, sedangkan produksi tersedikit ialah produksi bayam dengan $739 \mathrm{~kg}$. Gerombol keempat produksi terbanyak ialah produksi cabai rawit dengan $16.557 \mathrm{~kg}$ dan produksi terung dengan $13.296 \mathrm{~kg}$, sedangkan produksi tersedikit ialah produksi bayam dengan $159 \mathrm{~kg}$ dan produksi kacang merah dengan $330 \mathrm{~kg}$, adapun produksi bawang daun yang tidak memproduksi pada gerombol 4 Kabupaten Minahasa Utara. Gerombol kelima produksi terbanyak ialah produksi labu siam dengan $38.455 \mathrm{~kg}$ dan produksi tomat dengan $32.186 \mathrm{~kg}$, sedangkan produksi tersedikit ialah produksi kacang merah dengan $180 \mathrm{~kg}$ dan produksi cabai rawit dengan $309 \mathrm{~kg}$. Gerombol keenam produksi terbanyak ialah produksi bawang daun dengan $230.200 \mathrm{~kg}$ dan produksi tomat dengan $135.337 \mathrm{~kg}$, sedangkan produksi tersedikit ialah produksi bayam dengan $147 \mathrm{~kg}$.

\section{Penutup}

5.1. Kesimpulan

1. Analisis penggerombolan hirarki terdapat 5 gerombol pada metode pautan tunggal, pautan lengkap, pautan rata-rata dan metode centroid sedangkan pada metode ward terdapat 6 gerombol. Metode ward gerombol 1 terdapat Kabupaten Bolaang Mongondow, Kabupaten Kepulauan Sangihe, Kota Bitung, Kabupaten Kepulauan Talaud, Kabupaten Minahasa Tenggara, Kabupaten Bolaang Mongondow Timur, gerombol 2 terdapat Kabupaten Bolaang Mongondow Utara, Kabupaten Kepulauan Sitaro, Kota Manado, Kota Kotamobagu, Kabupaten Bolaang Mongondow Selatan, gerombol 3 terdapat Kabupaten Minahasa, gerombol 4 terdapat Kabupaten Minahasa Utara, gerombol 5 terdapat Kota Tomohon, dan gerombol 6 terdapat Kabupaten Minahasan Selatan.

2. Berdasarkan perbandingan penggerombolan hirarki dengan menggunakan rumus CTM (Cluster Tightness Measure) pada metode pautan tunggal, pautan lengkap, pautan rata-rata dan metode centroid menghasilkan 0,054448 sedangkan pada metode ward menghasilkan 0,046549. Jadi dapat di simpulkan metode ward adalah metode yang terbaik karena menghasilkan nilai yang lebih kecil.

\subsection{Saran}

Pemerintah harus menyediahkan lahan lebih pada Kabupaten Bolaang Mongondow dan Kabupaten Bolaang Mongondow Timur agar produksi hortikultura pada kabupaten tersebut semakin meningkat. 


\section{REFERENSI}

[1] Mangunwidjaja, D, Sailah, I. 2009. Pengantar Teknologi Pertanian. Penebar Swadaya. Bogor.

[2] Bukhori, M. 2014. Sektor Pertanian Terhadap Pembangunan di Indonesia. [Skripsi]. Fakultas Pertanian Universitas Pembangunan Nasional "Veteran". Surabaya.

[3] Mattjik. A.A., dan I. M. Sumertajaya. 2011. Sidik Peubah Ganda. Departemen Statistik FMIPA-IPB. Bogor.

[4] Suharleni, F. 2003. Analisis Gerombol (Cluster Analysis) untuk Penggerombolan Kecamatan di Kabupaten Malang Berdasarkan Status Kemiskinan. [Skripsi]. Fakultas Matematika dan Ilmu Pengetahuan Alam Universitas Jember.

[5] Johnson, Richard A., dan Dean, Wichern, W. 2002. Applied Multivariate Statistical Analysis $6^{\text {th }}$ edition. Prentice-Hall. London.

[6] Roux, M. 1991. Basic Procedures in Hierarchical Cluster Analysis, Devillers, J., and W. Karcher. Editor, Applied multivariate Analysis in SAR \& Environmental Studies. Kluwer Academic Publisher. Dordrecht.

[7] Mongi, C., 2015,"Penggunaan Analisis Two Step Clustering Untuk Data Campuran", Jurnal deCartesian, 4(1) : 9-19.

[8] Simamora. 2005. Analisis Multivariat Pemasaran Edisi Pertama. PT. Gramedia Pustaka utama: Jakarta.

[9] Anderberg MR. 1973. Cluster Analysis for Application. Academic Press, New York.

[10] Gudono, Ph. D. 2011. Analisis Data Multivariat Edisi Pertama. BPFE. Yogyakarta.

[11] Handoyo, R. 2014. Perbandingan Metode clustering Menggunakan Metode Single Linkage Dan K-Means pada Pengelompokan Dokumen. Jurnal SIFO Mikroskil. 15(2):73-76.

[12] Hardle, W. 2007. Applied Multivariate Statistical Analysis. Berlin Springer. New York.

[13] Singgih, S. 2002. Buku Latihan SPSS Statistik Multivariet. PT Elex Komputindo. Jakarta.

[14] Sarfia. 2016. Penerapan Metode Ward pada Analisis Gerombol Hirarki (Studi kasus: Komoditas peternakan di Sulawesi Tenggara). [Skripsi]. Fakultas Matematika dan Ilmu Pengetahuan Alam Universitas Halu Oleo. Kendari.

[15] Hardius, U., dan Nurdin, S. 2013. Aplikasi Teknik Multivarite Untuk Riset Pemasaran. PT Grafindo Persada. Jakarta.

[16] Novita, Y. 2013. Perbandingan jumlah kelompok optimal Single Lingkage dan Complete Lingkage dengan indeks Validitas silhouette (studi kasus data pembangunan manusia jawa timur).
[Skripsi]. Universitas Negeri Malang. Malang.

[17] BPS. 2017. Statistik Pertanian. Badan Pusat Statistik. Sulawesi Utara.

Eva Damayanti (evhadamayanti31@gmail.com)

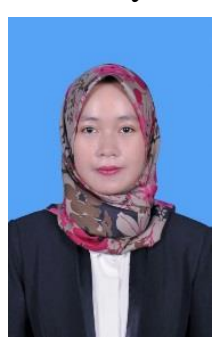

Lahir di Lamongan, Jawa Timur pada tanggal 23 Oktober 1997. Menempuh pendidikan tinggi di Jurusan Matematika FMIPA, Universitas Sam Ratulangi Manado. Tahun 2019 adalah tahun terakhir ia menempuh studi. Makalah ini merupakan hasil penelitian skripsinya yang dipublikasikan.

Charles E. Mongi (charlesmongi@unsrat.ac.id)

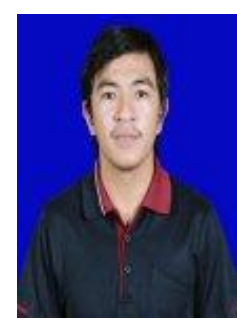
Lahir di Tondano, Minahasa Pada tanggal 4 januari 1984. Pada tahun 2006 memperoleh gelar sarjana pada program studi Matematika, Universitas Sam Ratulangi Manado, gelar Magister Sains diperoleh dari Institut Pertanian Bogor pada tahun 2014. Dan menjadi dosen dijurusan Matematika FMIPA Universitas Sam Ratulangi Manado Pada tahun 2008 sampai sekarang.

\section{Jantje D. Prang (jantjedprang@yahoo.com)}

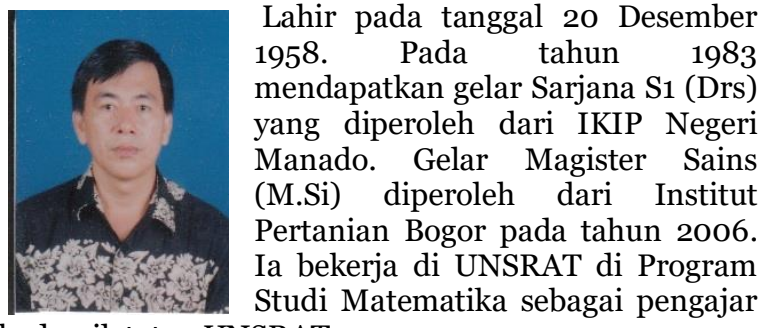
akademik tetap UNSRAT. 